\title{
The Design of One Push Danger Button Application Using Location Based Service (LBS) Technology For Public Security and Order As The Means of Actualizing Smart and Safe Village
}

\author{
Muhammad Arifin ${ }^{1}$, Wiwit Agus Triyanto ${ }^{2}$, Andy Prasetyo Utomo ${ }^{3}$, Supriyono ${ }^{4}$ \\ \{ arifin.m@umk.ac.id ${ }^{1}$, at.wiwit@umk.ac.id ${ }^{2}$, andy.prasetyo@umk.ac.id $\left.{ }^{3}\right\}$ \\ Study Program of Information System, Engineering Faculty, Universitas Muria Kudus, Kudus, \\ Gondangmanis Kudus Central Java - Indonesia, 59327 1234
}

\begin{abstract}
Village has important roles in supporting villagers social activity such as information, health, education even everything related to the public security and order is managed and handled by village. So far, the public security and order has been handled by the village government well. However, there is an obstacle namely late information. People have to go to village hall to report the incident happened and it causes the late handling. To overcome the problem, it is necessary to develop an information system which can help hastening the information conveying of danger / criminal act experienced by the people to the village government. The design of one push button application using location based service (LBS) technology for people security and order as the means of actualizing smar and safe village is expected to help the information conveying of danger / criminal act quickly just by pushing a button on smartphone application.
\end{abstract}

Keywords: village, security, order, smartphone, location based service.

\section{Introduction}

Village is a regional unit of regency under the sub-district which is assigned as technical implemeter in a certain area and is headed by a head of village. It has important roles in supporting the villagers social activity such as information, health, education, even everything related to the public security and order is managed and handled by village.

The increasingly growing and shopisticated technology gives impact in all aspects, including the aspect of village government. The advanced technology can provide easiness for villagers to do activity related to village government because all information can be conveyed quickly and on target. The use of information technology in all activities of village government is a form of smart village concept. By the application of smart village concept, villagers can keep up with the latest technology. Moreover it can be implemented in daily life. This certainly improves the competitiveness of villagers which will not be left far by urban people.

Security and order are important things in the sustainability of social activity because when they are not controlled, there will be a non condusive condition for villagers even people outside the village. Being a village that is away from urban area, and there are many quiet 
places, tends to be the source of criminal act or an act that is not accordance with ethic and social norm, such as theft, robbery, violent robbery, even persecution.

So far, the public security and order has been handled by the village government well. However, there is an obstacle namely late information. Victim has to go to village hall / village security officer to report the incident happened and it causes the late handling. Because of the late handling, the victim undergo massive loss and it takes longer time to find out the perpetrator of the crime.

To overcome the problem, it is necessary to develop an information system which can help hastening the information conveying of danger / criminal act experienced by people to village government. The design of one push button application using location based service (LBS) technology for people security and order as the means of actualizing smart and safe village is expected to help the conveying of danger information / criminal act quckly just by pushing a button on smartphone application. The application can also be used to report accident or anything that needs assistance handling from the village quickly. The system uses location based service (LBS) technology on smartphone, so that in addition to giving information of danger, it can also include the incident location automatically. This one push danger button application is also a form to achieve smart and safe village.

\section{Methodology}

\subsection{Review of Literature}

The result of reasearch conducted by Ramadhan, T. dan Utomo, V.G. (2014) about notification application stated that the existance of mobile application to access schedule which can provide schedule information automatically facilitates students to get an up to date schedule information [1]. The notification feature embedded in this application can remind students the lecture schedule for the semester. The ability of mobile schedule application which can provide notification precisely and accurately can not be saparated from the performance of officer in inputting lecture schedule.

Another research in the journal written by Saefullah, A., Ariyani, D. dan Rienauld, A. stated that for the utilization of android smartphone and internet network to run tantrian notification application can make user more utilize waiting time by doing activity or other activity and not have to queue directly in front of cashier [2]. The application of queue notification can provide facility of queue number taking without having to come as well as the information of cashier and payment queue.

A research about emergency call application by Dewantara, L., Sunaryono, D., Hariadi, $\mathrm{R}, \mathrm{R}$. stated that emergency call application using voice command was built with four major processes namely nearest public service call process, personal contact call process, location showing process and emergency message and emergency mode delivery process [3]. Voice recognition was performed by Android device by utilizing voice input API on Android. The translation of voice command was performed by command mathcing with some processes which can be called by voice command so that it could perform the process based on the voice command input. 


\section{Results And Discussion}

The system design used process model to illustrate activities performed and how data moved in the activities. The representation of model process used UML (Unified Modeling Language). UML is an architectural system that works with Object Oriented Arcitechture Design (OOAD) with a consistent languange to determine, visualize, construct and document artifact on Suhendar's software system [4].

\subsection{Use Case Diagram}

Class diagram represented system structure in terms of classes defining which will be created to build system. Class had attributes and methods or operations. Class diagram defines kinds of object in system and various static connection in class [5]. The following figure 1 represents use case on one push danger button application using location based service (LBS) technology on smartphone for people security and order as the means of actualizing smart and safe village:

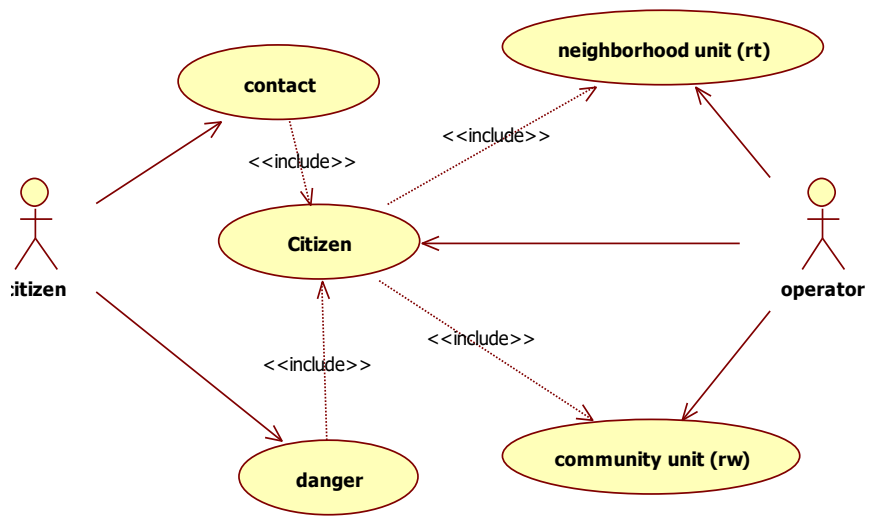

Fig. 1. Use Case Diagram of One Push Danger Button Application.

\subsection{Class Diagram}

The class diagram of this one push danger button application consisted of 7 classes namely class of citizen, rt, rw, contact, citizen and operator. The details and the relation are presented in figure 2 . 


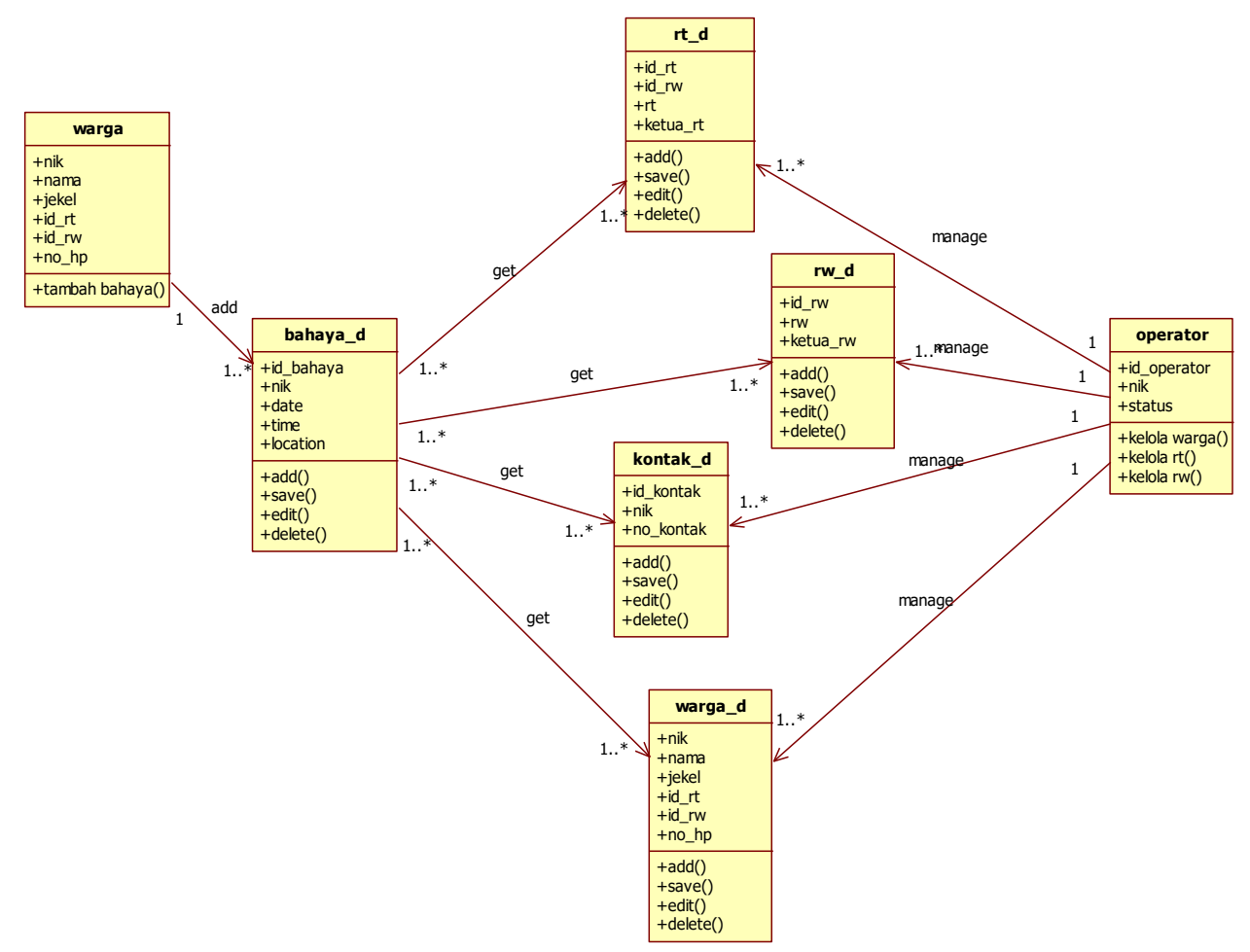

Fig. 2. Class Diagram of One Push Danger Button Application.

\subsection{Table Relation}

Table relation is a relation between tables in system, in which the relation is used to minimize errors in designing database. The relation table of the application is presented in figure 3 below: 


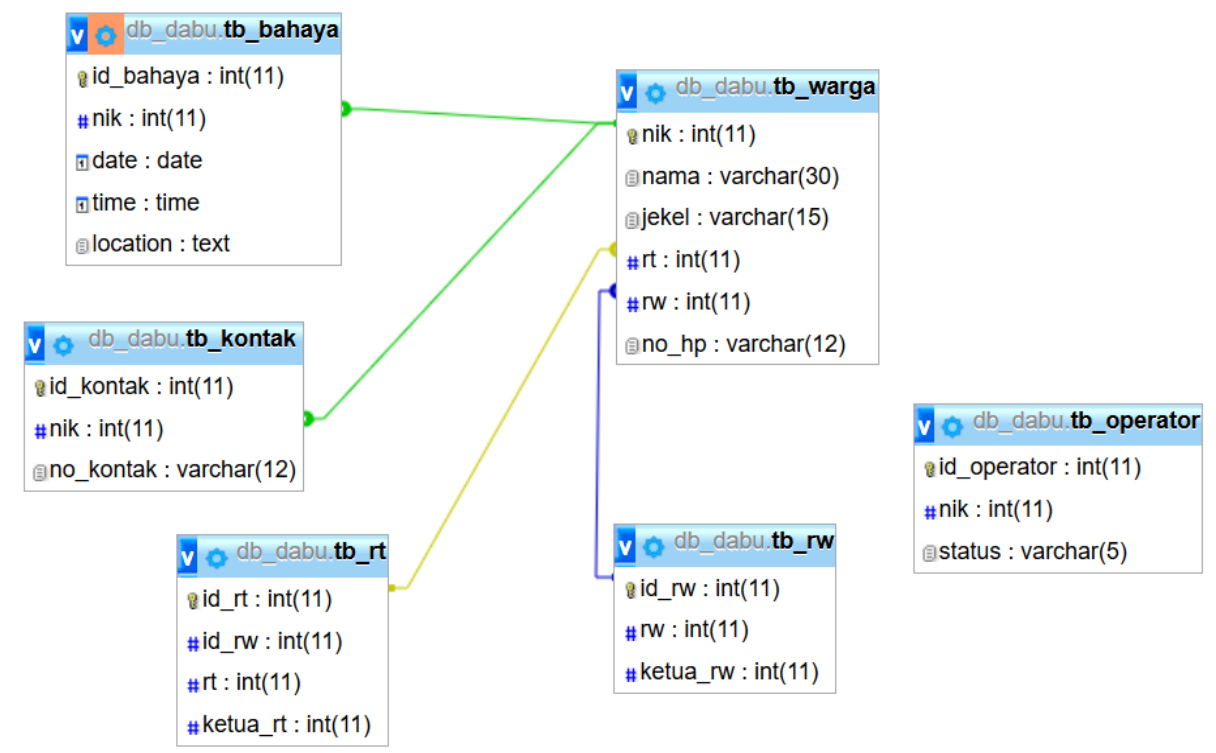

Fig. 3. Application Table Relation Diagram of One Push Danger Button Application.

\subsection{Database Structure}

1. tb_warga:

Primary Key $\quad$ : nik

Foreign Key

:-

Table 1. Table tb_warga.

\begin{tabular}{clll}
\hline No & \multicolumn{1}{c}{ Field } & \multicolumn{1}{c}{ Data Type } & \multicolumn{1}{c}{ Annotation } \\
\hline 1 & nik & Int & ID card number $(N I K)$ \\
2 & nama & Varchar & Name of Citizen \\
3 & jekel & Varchar & Gender of Citizen \\
4 & rt & Int & Neighbourhood Unit of Citizen $(R T)$ \\
5 & rw & Int & Community Unit of Citizen $(R W)$ \\
6 & no_hp & Varchar & Phone Number of Citizen \\
\hline
\end{tabular}

2. tb_kontak:

$\begin{array}{ll}\text { Primary Key } & : \text { id_kontak } \\ \text { Foreign Key } & : \text { nik }\end{array}$

Foreign Key

: nik 
Table 2. Table tb_kontak.

\begin{tabular}{clll}
\hline No & \multicolumn{1}{c}{ Field } & \multicolumn{1}{c}{ Data Type } & \multicolumn{1}{c}{ Annoation } \\
\hline 1 & id_kontak & Int & ID Contact of Citizen \\
2 & nik & Int & ID Card Number $(N I K)$ \\
3 & no_kontak & Varchar & Contact Number of Citizen \\
\hline
\end{tabular}

3. tb_bahaya:

$\begin{array}{ll}\text { Primary Key } & \text { : id_bahaya } \\ \text { Foreign Key } & \text { : nik }\end{array}$

Table 3. Table tb_bahaya.

\begin{tabular}{clll}
\hline No & \multicolumn{1}{r}{ Field } & \multicolumn{1}{c}{ Data Type } & \multicolumn{1}{c}{ Annoation } \\
\hline 1 & id_bahaya & Int & ID of Danger \\
2 & Nik & Int & ID Card Number $(N I K)$ \\
3 & Date & Date & Date of Danger \\
4 & Time & Time & Time of Danger \\
5 & Location & Text & Location of Danger \\
\hline
\end{tabular}

4. tb_rt:

$\begin{array}{ll}\text { Primary Key } & : \text { id_rt } \\ \text { Foreign Key } & : \text { id_rw }\end{array}$

Table 4. Table tb_rt.

\begin{tabular}{|c|c|c|c|}
\hline No & Field & Data Type & Annoation \\
\hline 1 & id_rt & Int & ID of $R T$ \\
\hline 2 & id_rw & Int & ID of $R W$ \\
\hline 3 & $\mathrm{Rt}$ & Int & $R T$ \\
\hline 4 & ketua_rt & Int & Head of $R T$ \\
\hline
\end{tabular}

5. tb_rw:

$\begin{array}{ll}\text { Primary Key } & \text { :id_rw } \\ \text { Foreign Key } & :-\end{array}$

Table 5. Table tb_rw.

\begin{tabular}{|c|c|c|c|}
\hline No & Field & Data Type & Annoation \\
\hline 1 & id_rw & Int & ID of $R W$ \\
\hline 2 & $\mathrm{Rw}$ & Int & RW \\
\hline 3 & ketua_rw & Int & Head of $R W$ \\
\hline
\end{tabular}

6. tb_operator:

$\begin{array}{ll}\text { Primary Key } & : \text { id_operator } \\ \text { Foreign Key } & : \text { nik }\end{array}$


Table 6. Table tb_operator.

\begin{tabular}{clll}
\hline No & \multicolumn{1}{c}{ Field } & \multicolumn{1}{c}{ Data Type } & \multicolumn{1}{c}{ Annoation } \\
\hline 1 & id_operator & Int & ID of Operator \\
2 & Nik & Int & ID Card Number $(N I K)$ \\
3 & Status & Varchar & Status \\
\hline
\end{tabular}

\subsection{Design of Program Input}

\section{Design of Add Citizen Data}

\begin{tabular}{l} 
Q Tambah Data Warga \\
NIK \\
Nomor Induk Kependudukan \\
Nama Lengkap \\
Nama Warga Kelamin \\
RT Pria $\bigcirc$ Wanita \\
\hline RT \\
RW \\
\hline RW \\
\hline No. HP \\
\hline Nomor HP \\
\hline Simpan Batal \\
\hline
\end{tabular}

Fig. 4. Design of Add Citizen Data. 
2. Design of Add Contact Data

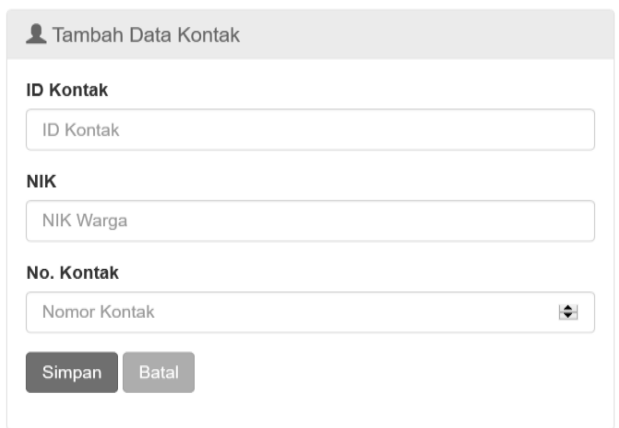

Fig. 5. Design of Add Contact Data

3. Design of Add Data of $R T$

\begin{tabular}{l}
2 Tambah Data RT \\
ID RT \\
\hline ID RT \\
RW \\
\hline RW \\
\hline RT \\
Ketua RT \\
\hline Nama Ketua RT \\
\hline Simpan Batal \\
\hline
\end{tabular}

Fig. 6. Design of Add Data of $R T$.

4. Design of Add Data of $R W$

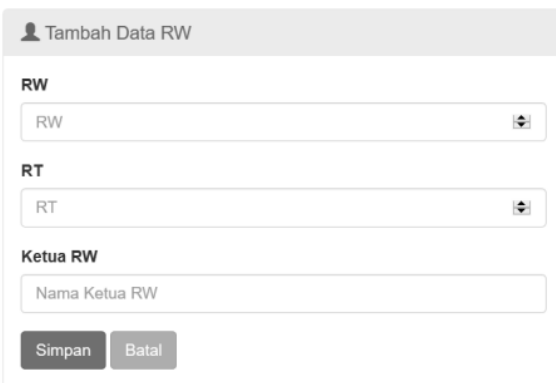

Fig. 7. Design of Add Data of $R W$ 
5. Design of Add Operator Data

\begin{tabular}{l}
2 Tambah Data Operator \\
ID Operator \\
ID Operator \\
NIK \\
Status \\
\hline Status \\
\hline Simpan Batal \\
\hline
\end{tabular}

Fig. 8. Design of Add Operator Data.

6. Design of Danger Button on Smartphone

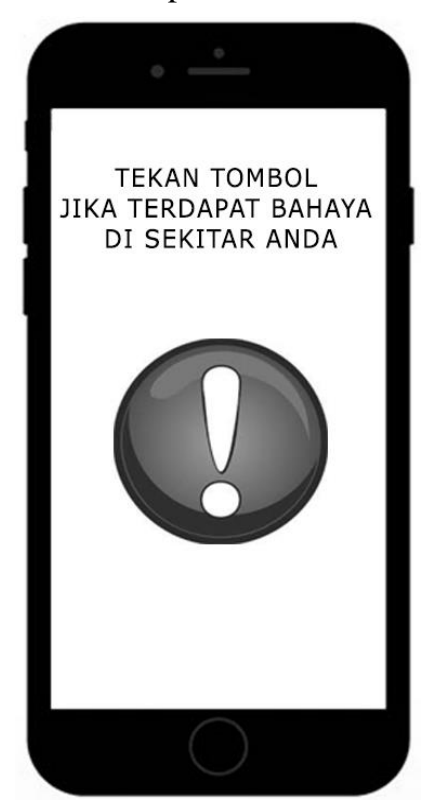

Fig. 9. Design of Danger Button . 


\section{Conclusion}

The conclusions of the research result and discussion are as follows: The design of the application produces 2 users that is Citizen and Operator, 7 classes that is warga, rt, rw, operator, bahaya, kontak, warga_d and 6 tables that is tb_bahaya, tb_warga, tb_kontak, tb_rt, tb_rw, tb_operator of database.

\section{References}

[1] V. . Ramadhan, T., Utomo, "Rancang Bangun Aplikasi Mobile Untuk Notifikasi Jadwal Kuliah Berbasis Android (Studi Kasus: STMIK PROVISI SEMARANG),” J. Teknol. Inf. dan Komun., vol. $5,2014$.

[2] A. Saefullah, A., Ariyani, D., Rienauld, "Sistem Notifikasi Antrian Berbasis Android," STMIK Raharja, vol. 7, 2014.

[3] R. R. Dewantara, L., Sunaryono, D., Hariadi, "Rancang Bangun Aplikasi Panggilan Darurat dengan Perintah Suara Berbahasa Indonesia pada Perangkat Bergerak Berbasis Android," J. Tek. Pomits, vol. 1, 2014.

[4] H. Suhendar, A. dan Gunadi, Visual Modelling Menggunakan UML dan Rational Rose. Bandung, 2002.

[5] Y. Sugiarti, Analisis dan perancangan UML (unified modeling language) generated VB.6: disertai contoh studi kasus dan interface web. Yogyakarta: Graha Ilmu, 2013. 